\title{
晶化焼結法によるコーディエライト焼結体の高温における変形挙動
}

\author{
林 國郎 ·長谷川充宏 $\cdot$ 近藤広恵 $\cdot$ 岡本泰則 $\cdot$ 上野建之*・瀬野 闊* $\cdot$ 稲田 勇* \\ 京都工芸絨維大学工芸学部物質工学科, 606-8585 京都市左京区松ヶ崎御所海道町 \\ *(株)村田製作所, 520-2313 滋賀県野洲郡野洲町大篠原 2288
}

\section{Deformation Behavior of Cordierite Ceramics Obtained by Densification/Crystallization of Glass Compacts at High Temperatures}

\author{
Kunio HAYASHI, Mitsuhiro HASEGAWA, Hiroe KONDO, Yasunori OKAMOTO, Kenji UENO*, \\ Hiroshi SENO* and Isamu INADA* \\ Department of Chemistry and Materials Technology, Kyoto Institute of Technology, Matsugasaki, Sakyo-ku, Kyoto-shi 606-8585
}

*Murata Manufacturing Co., Ltd., 2288, Yasu-cho, Yasu-gun, Shiga 520-2313

\begin{abstract}
Deformation behavior of four kinds of polycrystalline cordierites, fabricated by firing glass powder compacts at $1373 \mathrm{~K}$ for $1 \mathrm{~h}$ (heating rate of $6 \mathrm{~K} / \mathrm{min}$ or $20 \mathrm{~K} / \mathrm{min}$ ) was characterized by a four-point-bending creep test. The powder compacts had a composition $2 \mathrm{MgO} \cdot 2 \mathrm{Al}_{2} \mathrm{O}_{3} \cdot 5 \mathrm{SiO}_{2}$ and were eventually added with a small amount of $\mathrm{ZrO}_{2}$. The deformation of stoichiometric cordierite bodies obeyed a diffusional creep law at lower applied stresses, over the temperature range 1473-1523 K. On the other hand, accelerate creep deformation was observed with increasing the applied stress and over the whole range of stress applied at $1573 \mathrm{~K}$, resulting from crack nucleation and coalescence. Deformation behavior, considered to be represented by the steady state creep rate over the temperature range $1423-1473 \mathrm{~K}$, was monitored in cordierite bodies added with 1.8 mass $\% \mathrm{ZrO}_{2}$ as a nucleation agent. However, this creep deformation was due to intergranular crack growth, whose opening increased proportional to time. Creep rupture of cordierite bodies added with $\mathrm{ZrO}_{2}$ occurred at lower applied stresses and temperatures as compared to stoichiometric cordierite bodies.
\end{abstract}

[Received July 2, 1998; Accepted December 3, 1998]

Key-words : Creep deformation, Cordierite ceramics, Glass ceramics, Creep rupture, Densification and crystallization of glass

\section{1. 緒言}

前報1)では，熱衝撃試験の結果から，急速昇温・降温が繰り 返されるセラミックスの短時間焼成プロセスに耐えられるジグ 類として，コーディエライト組成を有するガラス圧粉体を熱処 理して得られた高純度多結晶焼結体が有用であることを報告し た. 言うまでもなく, セラミックス焼成用ジグ類は被焼成物を 支える役割をするものであるから，使用に当たっては耐熱衝撃 抵抗性とともに高温に打ける変形挙動を明らかにしておく必要 がある.

そこで, 本研究では, 先に晶化焼結法2)で作製した化学量論 比に極めて近い組成を有するコーディエライト焼結体の高温に おけるクリープ挙動を調べ, 少量の $\mathrm{ZrO}_{2}$ の添加が変形挙動に 及ほす影響についても検討した。

\section{2. 実 験}

\section{1 試料の調製}

コーディエライト組成 $\left(2 \mathrm{MgO} \cdot 2 \mathrm{Al}_{2} \mathrm{O}_{3} \cdot 5 \mathrm{SiO}_{2}\right)$ を有する平 均粒径 $5 \mu \mathrm{m}$ のガラス粉末（P-5）, 及びこれに 2 mass\%の $\mathrm{ZrO}_{2}$ を添加した同粒径のガラス粉末 (Z-5) の成形体を, 6 $\mathrm{K} / \min (\mathrm{L})$ ，及び $20 \mathrm{~K} / \min (\mathrm{H})$ で $1373 \mathrm{~K}$ まで昇温し $1 \mathrm{~h}$ 保持 することにより, $4 \times 25 \times 45 \mathrm{~mm}^{3}$ の板状焼結体 P-5L, P-5H, Z-5L，及びZ-5H を作製した. 表 1 に得られた焼結体の特性 を示す．昇温速度を大きくするとガラスからの結晶析出温度が 高温側にシフトするため ${ }^{3)}$, ガラス粒子の粘性流動による焼結 が促進される結果, $20 \mathrm{~K} / \mathrm{min}$ で昇温して得られた焼結体がい ずれも緻密化することは前報で報告した1).これらの焼結体か ら，ダイヤモンドブレードとダイヤモンド平行研削機を用いて 1 2 $2 \times 4 \times 36 \sim 40 \mathrm{~mm}^{3}$ の角柱状試片を採取し, 各面を鏡面に
Table 1. Characteristics of Cordierite Ceramics

\begin{tabular}{lccc}
\hline Sample & $\begin{array}{c}\text { Water } \\
\text { absorption } \\
\%\end{array}$ & $\begin{array}{c}\text { Apparent } \\
\text { porosity } \\
\%\end{array}$ & $\begin{array}{c}\text { Bulk } \\
\text { density } \\
\mathrm{g} \cdot \mathrm{cm}^{-3}\end{array}$ \\
\hline P-5L & 4.6 & 10.3 & 2.24 \\
P-5H & 1.3 & 3.1 & 2.38 \\
Z-5L & 0.8 & 2.0 & 2.42 \\
Z-5H & 0.1 & 0.2 & 2.51 \\
\hline
\end{tabular}

$\mathrm{L}: 6 \mathrm{~K} / \mathrm{min}, \mathrm{H}: 20 \mathrm{~K} / \mathrm{min}$

仕上げ，面取りを施したものをクリープ試験片とした．出発原 料の粒度分布, 化学組成, 成形プロセス, 焼結体の X 線回折 による同定結果は前報1)に詳述したので，ここでは省略する。

\section{2 クリープ試験}

得られた試験片を, 図 1 に示したバランス型定荷重負荷方式 クリープ試験機の電気炉中央部のアルミナ製上部エッジ（スパ

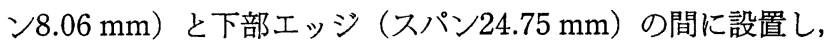
$10 \mathrm{~K} / \mathrm{min}$ の速度で, 所定の測定温度まで昇温した。測定系が 熱平衡状態に達した後, 一定荷重を負荷し 4 点曲げクリープ 試験を開始した.クリープ変形時の上部エッシの変位量は差動 トランスを用いて計測した。

\section{3 試料表面の観察}

クリープ試験前後の各試片の引張り面を走査型電子顕微鏡 (SEM ; 日立製作所製, S-2300型) を用いて観察した. 


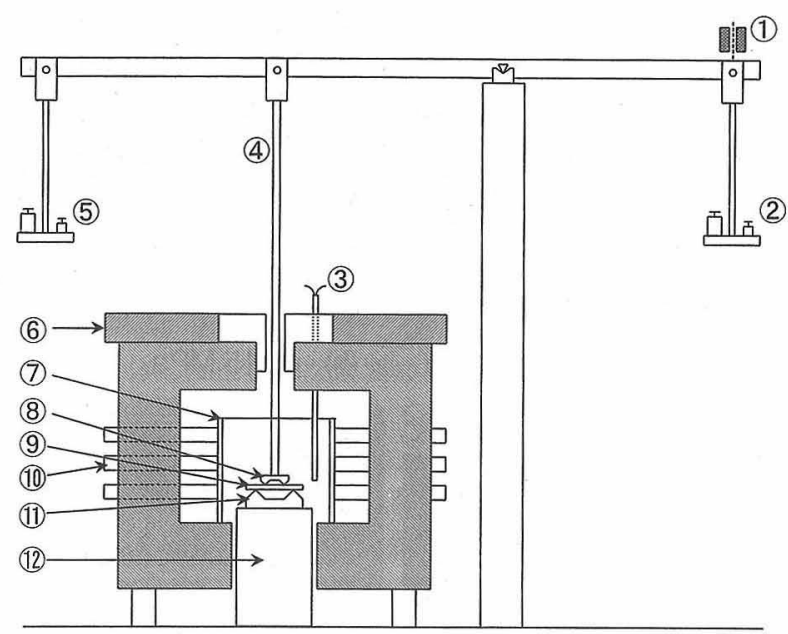

Fig. 1. Schematic drawing of apparatus for 4-point bending creep test.

1: Differential transformer, 2: Weight for balancing, 3:Thermocouple, 4: Alumina rod, 5: Weight for loading, 6: Water jacket, $7:$ Alumina muffe, $8:$ Upper edge, $9:$ Specimen, $10: \mathrm{SiC}$ heater, 11 : Lower edge, $12: \mathrm{SiC}$ rod.

\section{3. 結果と考察}

3.1 高純度コーディエライト焼結体のクリープ変形

図 2 及び図 3 は, 前報1)で耐熱衝撃抵抗性が最も大きいと判 断された高純度コーディエライト焼結体 P-5L に， $1473 \mathrm{~K}$ と $1573 \mathrm{~K}$ において種々の応力 $\sigma$ 負荷した場合の, 試料が破壊 するまでの間の, 引張り面のひずみ $\varepsilon$ の時間的変化を示したも のである．例えば, $30 \mathrm{MPa} の$ 応力を負荷した場合では約 $10^{5}$ $\mathrm{s}$ 後, 約 $1.6 \%$ ひずんた時点で試料が破断したことになる. 図 2 から分かるように, $10 \sim 40 \mathrm{MPa}$ の負荷応力範囲の $\varepsilon$-時間曲 線にはいずれも定常クリープ域が観察されている.このこと

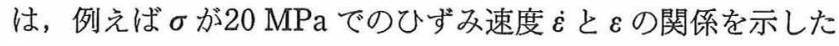
図 4 で, $\varepsilon$ が0.8\%以上でほぼ一定になっていることからも確 認できる.これに対して，1573 K での測定結果（図 3）には, $\sigma$ が $10 \mathrm{MPa}$ 以上で $\varepsilon$-時間曲線が下に凸となる加速域が観察さ れた。このような領域の $\dot{\varepsilon}-\varepsilon$ 曲線は図 5 にみられるように, 例

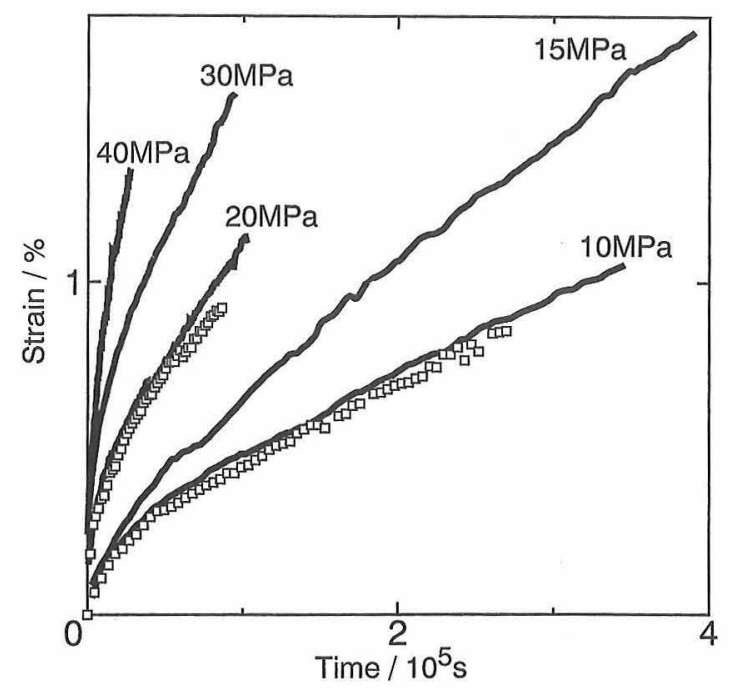

Fig. 2. Creep curves for $\mathrm{P}-5 \mathrm{~L}$ and $\mathrm{P}-5 \mathrm{H}$ at various applied stresses at $1473 \mathrm{~K}$. - : P-5L, $\square:$ P-5H

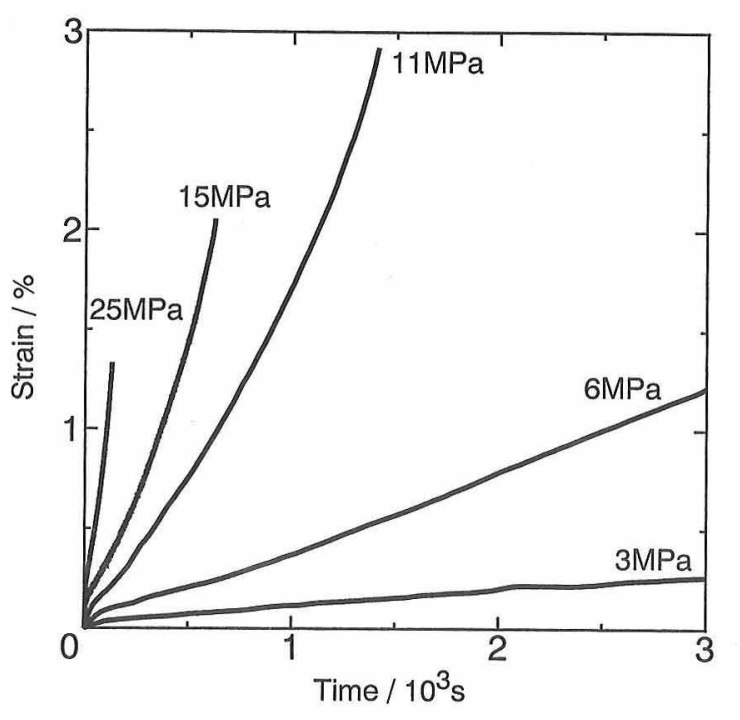

Fig. 3. Creep curves for P-5L at various applied stresses at $1.573 \mathrm{~K}$.

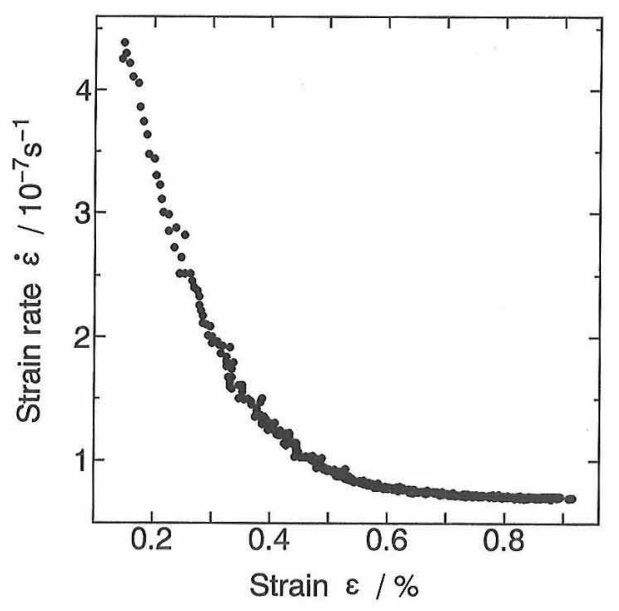

Fig. 4. Relation between strain rate and strain for P-5L under loading of $20 \mathrm{MPa}$ at $1473 \mathrm{~K}$.

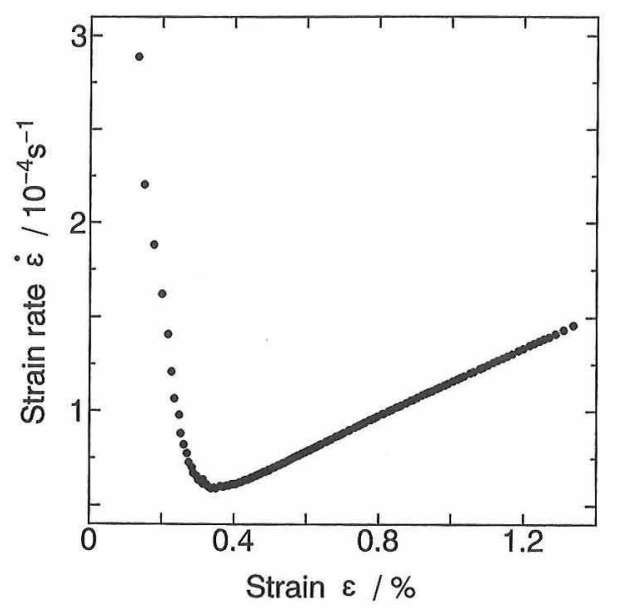

Fig. 5. Relation between strain rate and strain for P-5L under loading of $25 \mathrm{MPa}$ at $1573 \mathrm{~K}$. 


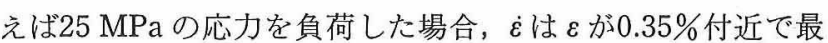
低となり，これを超えると它は急激に増加する，いわゆる加速 域に移行することが分かる。このような変形挙動は, 純度 96 mass\%のアルミナ焼結体においても観察されている4). 図 2 中 の口印で示した曲線は, $20 \mathrm{~K} / \mathrm{min}$ の昇温速度で焼成した P$5 \mathrm{H}$ の代表的なクリープ曲線である. 表 1 より明らかなように， P-5H は P-5L より維密な焼結体であるので，その分同一時間 での $\varepsilon$ 量は小さくなったが, 変形挙動には大きな差はなかった ので，ここでは P-5L について考察をすすめる.

$\varepsilon$-時間曲線に定常域が認められたものについてはそのををを定 常ひずみ速度とし, 定常域が存在しないものについては, 加速 域に移行する直前の最小ひずみ速度をその試料の实として，

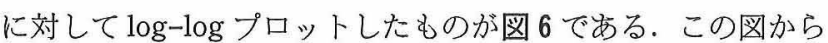

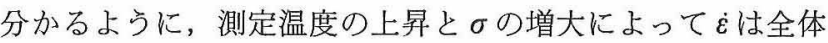
的に増加した。測定温度が $1473 \mathrm{~K}$ と1493 K では，それぞれ $\sigma$ が最小と最大の場合を除くと, 両者の間に勾配 $n$ が前者で 1.1, 後者で1.2の直線関係が成り立つことが分かる. $1523 \mathrm{~K}$ の場合では, 低応力域でのみ $n=1.1$ 直線関係が認められる が， $\sigma$ が $5 \mathrm{MPa}$ を超えると測定值はこの直線から逸脱し1573 $\mathrm{K}$ の場合のように急激に増大した。

図 7 に各温度において，種々の応力を負荷し所定のひず久量 まで变形させた後の試料の引張り面のSEM による観察結果を 示す. 図 6 に扔いて $\dot{\varepsilon}$ と $の$ 間に直線関係が成り立つ応力範 囲での変形後の引張り面である図 7 (b), (c), 及び(d)には, クリープ試験前の試料表面(a) と比べて微細組織に変化した様 子は観察されなかった. したがって, 直線性が認められる応力 範囲ではその勾配が約 1 であることから，これらの変形は Nabarro-Herring の速度式(5)満たす拡散クリープとみなすこ とができる。

上述の $n \fallingdotseq 1$ を示した温度, 及び負荷応力範囲でのクリープ 試験で得られた $\dot{\varepsilon} \sigma$ で規格化し, 絶刘温度に対してプロッ 卜したものが図 8 である. 測定温度が 3 点ではあるがこれを 結ぶ直線の勾配から变形の活性化エネルギーを計算した結果,

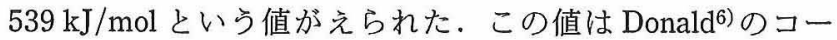
ディエライトガラスの結晶化の活性化エネルギーの值 (577

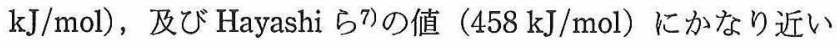
ものである.

ガラス圧粉体の結晶化は, 粒子表面から中心に向かって進行 するので9), 出発ガラス粉末粒子が必ずしも単結晶に成長する

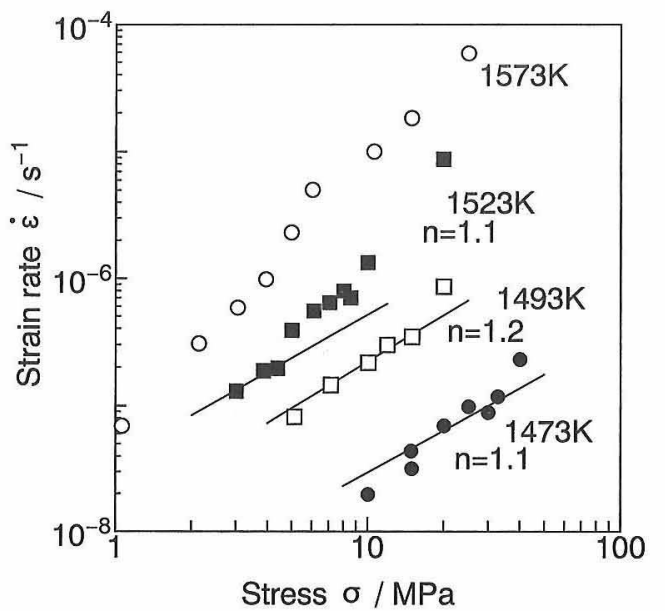

Fig. 6. Stress dependence of strain rate for $\mathrm{P}-5 \mathrm{~L}$ at various temperatures.

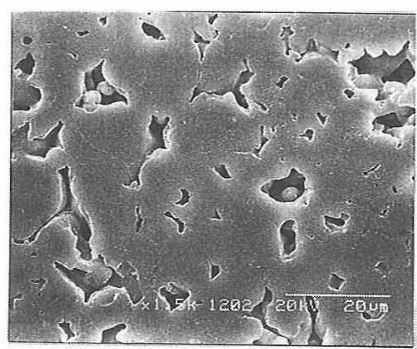

(a) before deformation

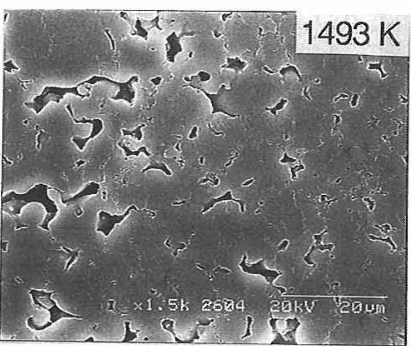

(c) $\sigma: 10 \mathrm{MPa}, \varepsilon: 2.2 \%$

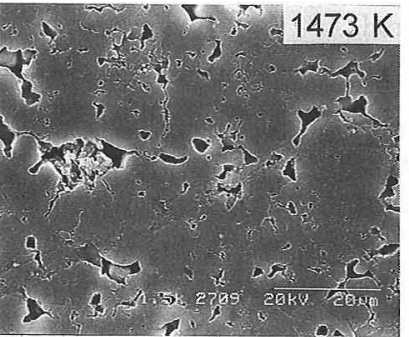

(e) $\sigma: 33 \mathrm{MPa}, \varepsilon: 2.1 \%$

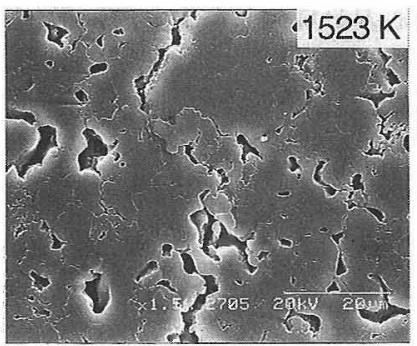

(g) $\sigma: 8 \mathrm{MPa}, \varepsilon: 2.3 \%$

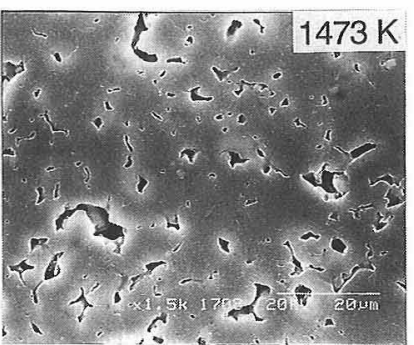

(b) $\sigma: 15 \mathrm{MPa}, \varepsilon: 1.2 \%$

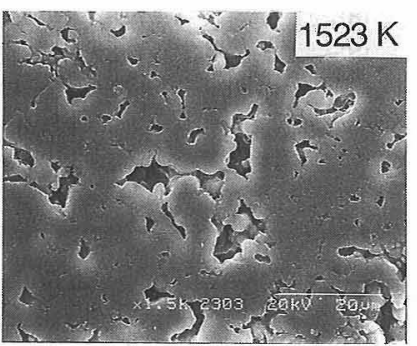

(d) $\sigma: 14 \mathrm{MPa}, \varepsilon: 2.1 \%$

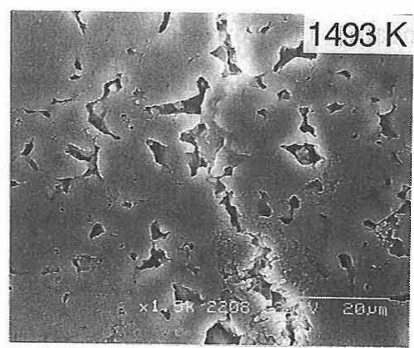

(f) $\sigma: 15 \mathrm{MPa}, \varepsilon: 2.5 \%$

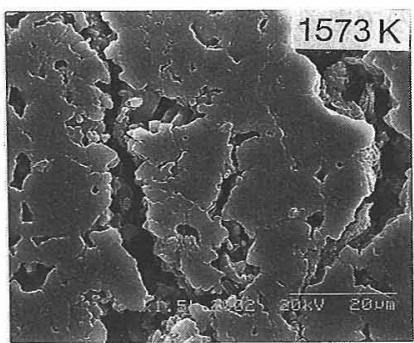

(h) $\sigma: 3 \mathrm{MPa}, \varepsilon: 3.5 \%$

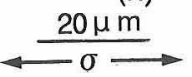

Fig. 7. Tensile surfaces for P-5L before and after flexural creep at various temperatures.

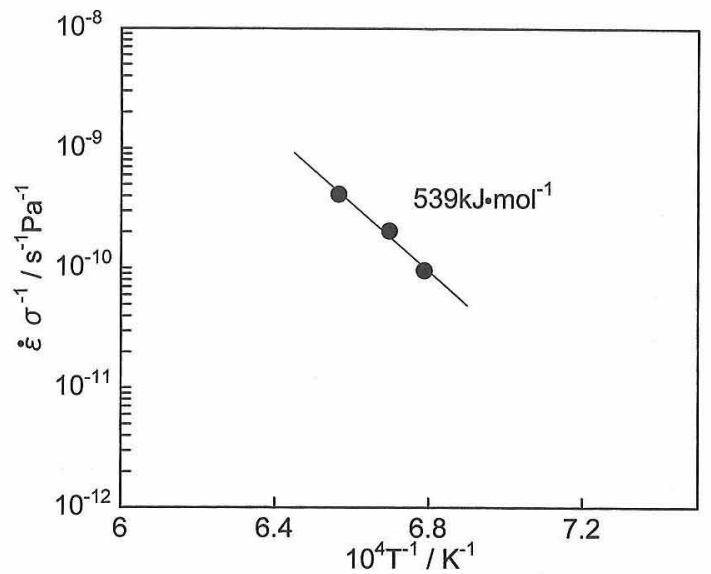

Fig. 8. Temperature dependence of strain rate normalized with stress for P-5L. 
とは限らないため, 試料の結晶粒径を測定できなかった。した がって, 変形を律速する拡散種が何であるかは特定できない が, 上述のように, 活性化エネルギーにかなりよい一致がみら れたことから, 変形とガラスからの結晶化を律速している拡散 種は同一のものと推察できる.

一方, $1473 \mathrm{~K}$ における33 MPa, $1493 \mathrm{~K}$ における $15 \mathrm{MPa}$, 及び $1523 \mathrm{~K}$ における $8 \mathrm{MPa}$ の応力での試験後の引張り面であ る図 7 (e)，(f)，及び(g)には, 変形中に発生したキャビティー と気孔が合体した巨視的な亀裂の発生が引張り方向に対して垂 直に多数観察された. したがって，この亀裂の発生が $\dot{\varepsilon}$ を増加 させた原因と考えれば, 図 6 にみられた直線関係からの逸脱 は首肯できるもので, 急速な亀裂進展によるものと結論付けら れた純度 96 mass\%のアルミナ焼結体で観察された現象 ${ }^{4}$ に類 似したものといえる.

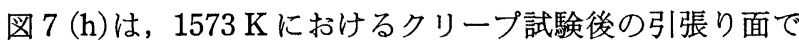
ある. 図から分かるように, $3 \mathrm{MPa}$ の応力ですでにキャビ ティーの発生がみられ， $\sigma$ が大きくなるに従って亀裂が進展し ていることから，亀裂の生成とその開口が $\dot{\varepsilon}$ を極端に増大させ た原因となったものと思われる。

以上のことから，1473～ $1523 \mathrm{~K}$ までの低応力範囲では構成 原子やイオンの拡散が変形を律速しているのに対し, 高応力, 及び $1573 \mathrm{~K}$ では, 亀裂の発生と開口によって極めて大きい速 度で見掛けの变形が進行したとものと考えられる.

\section{$3.2 \mathrm{ZrO}_{2}$ を含むコーディエライト焼結体のクリープ変形}

図 9 及び図10は, $\mathrm{ZrO}_{2}$ を1.8 mass\%含むコーディエライト ガラス圧粉体を， $6 \mathrm{~K} / \mathrm{min}$ と $20 \mathrm{~K} / \mathrm{min}$ の昇温速度で熱処理し て得られた焼結体 Z-5L と Z-5H について, $1473 \mathrm{~K} て ゙$ 種々の 応力 $\sigma$ を負荷した場合の $\boldsymbol{\varepsilon}$-時間曲線を示したものである。こ れらの図から，先の $\mathrm{P}$ 系と同様に低応力では定常クリープと みられる直線性が観察され， $\sigma$ の増大に伴って早期から加速ク リープ域が認められる.これらの図と図 2 を比べると, 同じ 変位量に達するまでの時間が, Z-5L は P-5 (L, H) の約 $1 / 10$ であり，Z-5H は Z-5L の約 1/10であることから， $\mathrm{ZrO}_{2}$ を含 む焼結体はより短時間で変形し， $\mathrm{ZrO}_{2}$ を含まない焼結体では 認められなかった王粉体の熱処理時における昇温速度の影響が 顕著にあらわれた.

図11は, $1473 \mathrm{~K}$ 前後の温度範囲で $20 \mathrm{MPa}$ の応力を負荷し

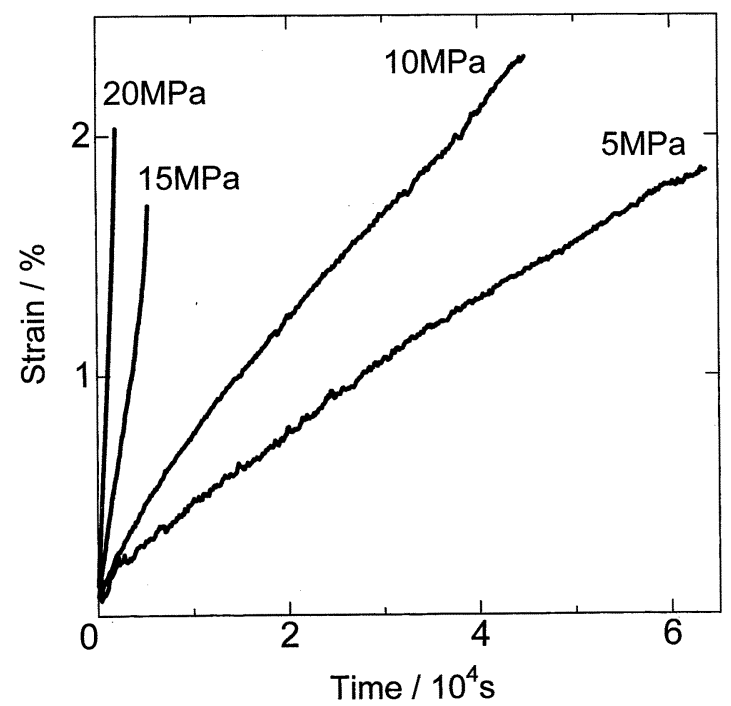

Fig. 9. Creep curves for $\mathrm{Z}-5 \mathrm{~L}$ at various applied stresses at $1473 \mathrm{~K}$.

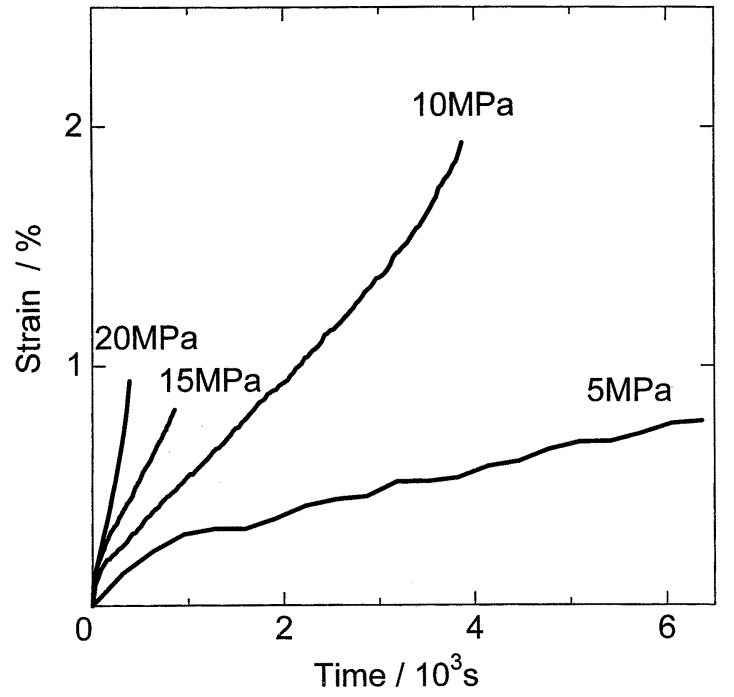

Fig. 10. Creep curves for $\mathrm{Z}-5 \mathrm{H}$ at various applied stresses at $1473 \mathrm{~K}$.

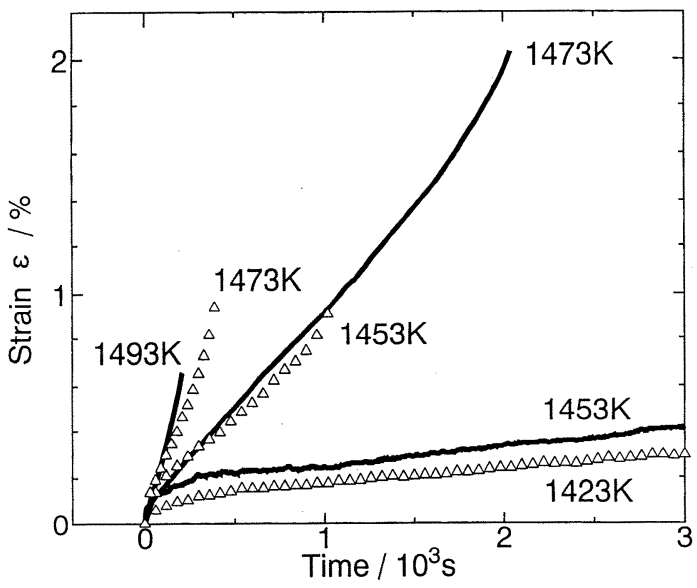

Fig. 11. Creep curves for Z-5L and Z-5H under loading of 20 $\mathrm{MPa}$ at temperatures ranging from 1423 to $1493 \mathrm{~K}$. - : Z-5L, $\triangle: Z-5 \mathrm{H}$

た場合の試料の $\boldsymbol{\varepsilon}$-時間曲線を示したものである. 実線で示し た Z-5L と $\triangle$ 印で示した Z-5H の変形曲線を比較すると, 同量 のひずみが生じる温度が後者に比べて前者の方が約 $20 \mathrm{~K}$ 高い ことが分かる．このことは，Z系においては, 緻密に焼結した むのの方がクリープ特性が劣ることを意味している.

図12は, 各温度において, 種々の応力を負荷し所定のひずみ 量まで変形させた後の試料の引張り面の SEM による観察結果 を示したものである. 図12(a)は, クリープ曲線では直線性が

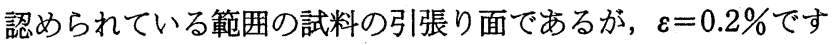
でにキャビティーの発生と合体による亀裂が多数認められる. このことから, クリープ曲線に観察された定常域は, 試験中に 亀裂の発生とその開口が時間に比例して増加したことによる単 なる見掛けの現象で, 拡散が変形を律速したものではないこと は明らかである.クリープ曲線に加速域が認められた試料の代 表的な引張り面には, 図12(b)に示したように $\mathrm{P}$ 系と同様に多 くの亀裂が観察されることから, 亀裂の生成とその開口が見掛 けの変形を極端に増大させる結果になったものと思われる.こ のように, Z 系では見掛け上のクリープ変形が拡散 ${ }^{5)}$ や転位の 


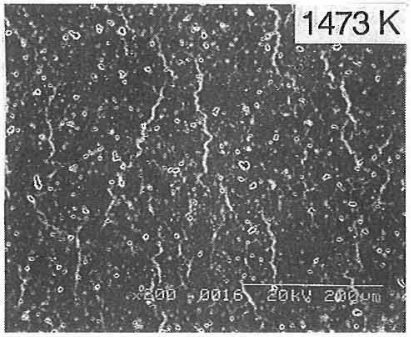

(a) $\sigma=5 \mathrm{MPa}, \quad \varepsilon=0.2 \%$

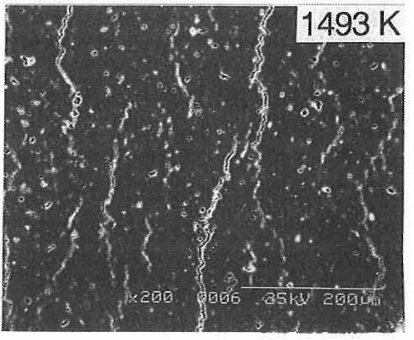

(b) $\sigma=10 \mathrm{MPa}, \varepsilon=1.5 \%$ $\stackrel{200 \mu \mathrm{m}}{\longleftarrow \sigma \longrightarrow}$

Fig. 12. Tensile surfaces for Z-5L after flexural creep at 1475 and $1493 \mathrm{~K}$.

上昇8)などによって律速されたものではないので，これまで提 案されてきているクリープ速度に関する理論でその機構を解析 することはできなかった.

\section{3 変形挙動に及ぼす微細組織の影響}

$\mathrm{P}$ 系に比べて Z 系の方が変形に要する時間が短いこと，拡 散が律速するクリープ条件が見いだせなかったこと, 及び $\mathrm{P}$ 系には認められなかった熱処理時の昇温速度の影響が Z系に 見られたことについては，以下のことが考えられる.ガラス圧 粉体を熱処理するとガラス粒子は粘性流動により焼結し，粉哗 時に粒子表面に付着した不純物が核となって結晶が内部に向 かって成長する99,10)。この際，ガラス内部からの結晶化を促進 させる目的で $\mathrm{ZrO}_{2}$ を少量添加した $\mathrm{Z}$ 系では, コーディエライ トガラスより安定な $\mathrm{MgO}-\mathrm{Al}_{2} \mathrm{O}_{3}-\mathrm{SiO}_{2}-\mathrm{ZrO}_{2} 4$ 成分系ガラスに なることにより，核生成剤11)の役割よりも焼結時における粘 性に影響を及ぼし，ガラス状態での緻密化を促進させる結果と なった．また，この種のガラス王粉体を熱処理する際に昇温速 度を大きくすると，先にも述べたようにガラスからの結晶析出 温度が高温側にシフトする．したがって，ガラス粒子は結晶化 することなくより高温にさらされる結果，ガラスの粘性が下が りその流動による焼結が進行すると同時に，粉碎時にガラス粒 子表面に付着した不純物との反応も進み，比較的安定なガラス 相が昇温速度の小さい場合にくらべて, より広い幅で粒子境界 に介在することが考光られる（図13），その結果，Z系，及び これを大きい昇温速度で熱処理して得られた焼結体は高温にお いてこの粒界ガラス相の強度が低下しこここを選択的に刍裂が 進展したため，変形に拡散が追従できず，変形の本質は，亀裂 の発生とその開口にあったと思われる。

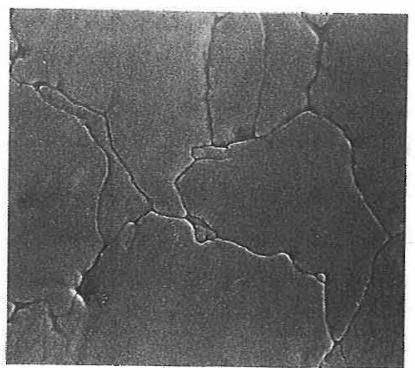

(a) $P-5 L$

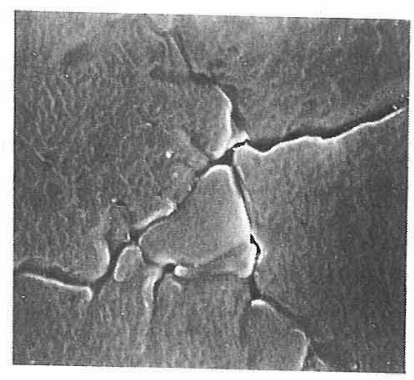

(b) $Z-5 L$ $3 \mu \mathrm{m}$

Fig. 13. SEM micrographs of surfaces for $\mathrm{P}-5 \mathrm{~L}$ and $\mathrm{Z}-5 \mathrm{~L}$ after etching with EDTA.

\section{4 コーディエライト焼結体の耐用性}

一般にセラミックスを焼成用ジグ類のように高温で長時間使 用しようとする場合, それらの耐用年数が重要な問題となる. 実用に当たっては実際の使用条件下で試験を行うことが肝要で あるが，このような試験には長時間を要するので，種々の方法 での耐用寿命の予測が行われている．それらの中で，本実験の ようにクリープ破壊を扢こす場合に対しては Monkman と Grant ${ }^{12)}$ やLarson と Miller ${ }^{13)} に よ り ，$ 最低ひずみ速度 $\dot{\varepsilon}_{\min }$ と 破壞時間 $t_{\mathrm{f}}$, あるいは負荷応力と破壞時間の経験則から, 破壞 に至る時間の予測の可能性が示唆され，セラミックスに対する 実験結果の整理も試みられた。しかし， $\dot{\varepsilon}_{\min }$ と $t_{\mathrm{f}}$ の積が一定值 $b$ になるというMonkman とGrant の式 ${ }^{12)}$ ，すなわち

$$
t_{\mathrm{f}} \dot{\varepsilon}_{\min }^{a}=b
$$

の指数 $a=1$ で成立するひずみ量に比べて，ひずみ量がはるか に小さいセラミックスの場合には，一定でめるぺき $b$ 值が温 度, 及び負荷応力に依存し(1)式が成り立たない場合が多いこ とが報告されている4),14),15).

そこで，本研究の試料のようにガラス粉末の接点でおこる焼 結々結晶化によって得られた多結晶焼結体の高温でのクリープ 破壤データが，(1)式で整理できるかどうかを検討してみた. 図14, 及び図15は，P-5L の1473 1573 K の範囲, 及びZ5L とZ-5H の1423〜1523 K の範囲でクリープ破壊した試料 の, 各 $\dot{\varepsilon}_{\text {min }}$ を故に対して $\log -\log$ プロットしたものである. 図 14から分かるように，若干のばらつきはあるが P-5L の測定 值は直線で結ぶことができ，その勾配はほぼ1であった。こ のことは，(1)式が試験温度や負荷応力に依存せずに成り立ち, $a=1$ となるという Monkman と Grant ${ }^{12)}$ の主張を満足するも のであった. しかしながら, 上述の化学量論比に近い組成の焼 結体に対する結果と比べて，Z系の方は，図15から分かるよう に, Z-5H の $1423 \mathrm{~K}$ のデータ（@印で示したもの）を除くと, L系，H系共にそれぞれ 1 本の直線で結ぶことはできたが，

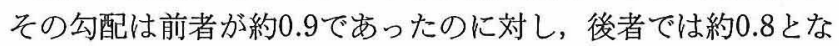
り小さい值となった.このことは, 高温における荷重下で残存 ガラス相（図14，及び15中にを示した点線は，4 mass\%のガ ラス相を含むアルミナ焼結体についての Wiederhorn ら4)のク

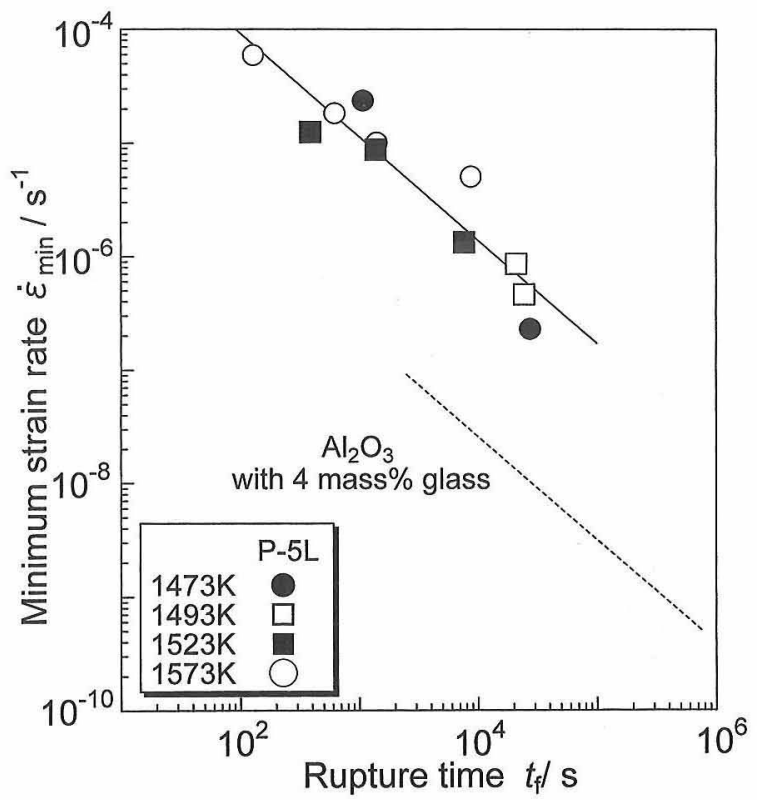

Fig. 14. Relation between minimum strain rate and rupture time for P-5L. 


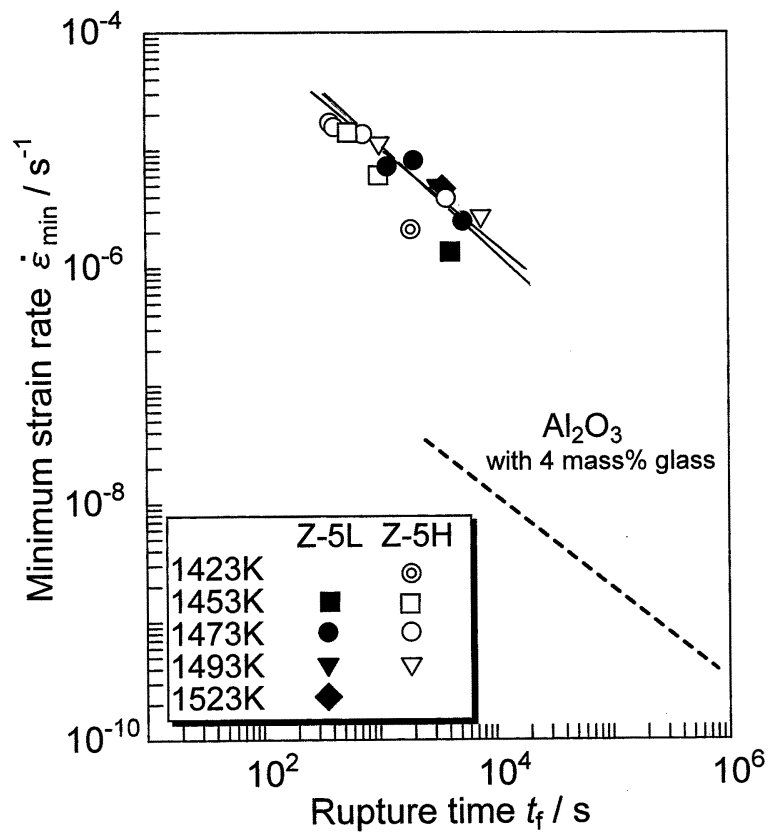

Fig. 15. Relation between minimum strain rate and rupture time for $\mathrm{Z}-5 \mathrm{~L}$ and $\mathrm{Z}-5 \mathrm{H}$.

リープ破壊データであるが，これと比較すると，いずれの試料 も同じ $\dot{\varepsilon}_{\min }$ において $t_{\mathrm{f}}$ の值が約 2 けた大きいことから，量的 にはかなり少ない）に発生したキャビティーが合体して生じた 亀裂の開口が，見掛けのクリープ変形の加速域と見なせるよう な挙動をとる材料には(1)式は適合しないことを意味してい る.

また，図15において，L系に比べて残存ガラス相が多いと

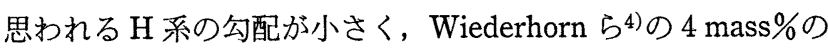
ガラス相を含むアルミナのデータに近い值になったのは，この 系ではすべての試験温度, 負荷応力範囲において, 真の定常ク リープ域が観測されなかったことから，図５に示したような 加速域にはいる寸前のひずみ速度を $\dot{\varepsilon}_{\min }$ としたために， $\dot{\varepsilon}_{\min }$ を 過大評価したことが最大の原因であると推測される。

上述のような定常クリープ域があらわれない変形を含めて, クリープ破壊データを正確に整理するためには, 高温での粒界 におけるキャビティーの発生と成長のモデルの構築が不可欠と 思われる. Blanchard とChan ${ }^{16)}$ はルカロックスとガラスを含 むアルミナとのキャビテーション機構の考察を行い, 単一相セ ラミックスでは，キャビティー核生成は空孔の桩散によって制 御されるが，ガラス相を含むセラミックスでは表面エネルギー と粘性との和によって制御されることを報告しており，一部物 理的 ${ }^{17)}$ や統計論的な立場18) からのアプローチもなされている が，界面（粒界や表面）での物質移動に関する問題は複雑で評 価しにくいため, 現実の系への適用が困難である.したがっ て, 現時点での厳密な寿命予測は不可能ではあるが, 本実験結 果が基礎データとして今後のこの分野における研究の発展に何 らかの寄与ができるものと考えている.

このような背景をふまえて, 高温構造材料としての実用面か らの耐用性を, 変形後の試料の表面状態の観察を通して主とし て現象論の立場でとらえた上述の結果を総合すると，高温にお ける耐クリープ性を向上させるためには，ガラス粒子表面が十 分に結晶の析出を促すので, 粒界にガラス相を残すような核生 成剤は添加せず，化学量論比のコーディエライト組成ガラスを 出発原料とする方が得策であることが分かった。 また，クリー
プ破壊を起こすこの種の材料では寿命予測が実用上不可欠とな るので，現在，動的疲労試験を行っている.

\section{4. 総 括}

コーディエライトの化学量論比に極めて近い組成を有するガ ラス，並びにそれに少量の $\mathrm{ZrO}_{2}$ を含むガラス圧粉体を1373 $\mathrm{K}$ で $1 \mathrm{~h}$ 熱処理して得られたコーディエライト多結晶焼結体の 高温における変形挙動を調べた. 得られた結果は次のようであ る.

（1）高純度コーディエライト焼結体は，1473～1523 K の 温度範囲で拡散によって律速された変形が低負荷応力時にみら れたが, 負荷応力の増大, 及び $1573 \mathrm{~K}$ での試験では, いずれ も亀裂の発生による加速的な变形挙動が観察された.

(2) $\mathrm{ZrO}_{2}$ を含むコーディエライト焼結体の変形は, 1423 〜 $1473 \mathrm{~K}$ の温度範囲で定常クリープとみなせる変形現象が認 められたが, 微細構造の観察結果から, 粒界亀裂の発生とその 開口が単に試験時間に比例して増加しただけのものであった.

(3) 化学量論組成のコーディエライト焼結体と比較して $\mathrm{ZrO}_{2}$ を含む焼結体は, より低い負荷応力, 並びに温度で亀裂 が発生し合体を起こしてクリープ破壊した.

（4）クリープ破壊した試料の最低ひずみ速度と破壊に至る 時間の関係を調べた結果, いずれも試験温度や負荷応力に依存 しないことが分かった。しかしながら，コーディエライト組成 の焼結体における定数 $a$ はほほ 1 となり, Monkman と Grant の式で整理できたが, 定常クリープ域が観測されなかっ た $\mathrm{ZrO}_{2}$ を含む試料では, 最低ひずみ速度を過大評価する結果 となったため, $a$ 值は 1 より小さくなった.

謝辞 原料ガラス粉末の作製に御協力頂いた日本フエロー 株式会社・谷口謙治部長に感謝の意を表します。

\section{文献}

1) K. Hayashi, M. Hasegawa, Y. Okamoto, K. Ueno, H. Seno and I. Inada, J. Ceram. Soc. Japan, 106, 385-89 (1998) [in Japanese].

2）上井 勲, 旭硝子工業技術奖励会研究報告, Vol. 9 (1963) pp. 47-62.

3）上井 勲, 旭硝子工業技術奖励会研究報告, Vol. 9 (1963) pp. 63-75.

4) S. M. Wiederhorn, B. J. Hockey, R. F. Krause, Jr. and K. Jakus, J. Mater. Sci., 21, 810-24 (1986).

5) C. Herring, J. Appl. Phys., 21, 437-51 (1950).

6) I. W. Donald, J. Mater. Sci., 30, 904-15 (1995).

7) K. Hayashi, M. Okuno, Y. Okamoto and T. Nishikawa, $J$. Ceram. Soc. Japan (Seramikkisu Ronbunshi), 98, 1070-75 (1990) [in Japanese].

8) F. R. N. Nabarro, Phil. Mag., 16, 231-36 (1967).

9) I. Uei, K. Inoue and M. Fukui, J. Ceram Soc. Japan (YogyoKyokai-Shi), 74, 325-35 (1966) [in Japanese].

10) K. Watanabe, J. Am. Ceram. Soc., 66, 53-58 (1985).

11) M. Tashiro and M. Wada, "Advances in Glass Technology," Part 2, Plenum Press, New York, London (1963) p. 18.

12) F. C. Monkman and N. J. Grant, Proc. Am. Soc. for Testing and Mater., Vol. 56, 593-620 (1956).

13) F. R. Larson and J. Miller, Trans. ASME, 74, 765-75 (1952).

14) S. M. Johnson, B. J. Dalgleish and A. G. Evans, J. Am. Ceram. Soc., 67, 759-63 (1984).

15) Y. Okamoto, H. Fukudome, K. Hayashi and T. Nishikawa, J. Eur. Ceram. Soc., 6, 161-68 (1990).

16) C. B. Blanchard and K. S. Chan, J. Am. Ceram. Soc., 76 , 1651-60 (1993).

17) H. Riedel, "Fracture at High Temperature," SpringerVerlag, Berlin, Heidelberg, New York, London, Paris, Tokyo (1987) pp. 86-102.

18) A. G. Avans and A. Rana, Acta Metall., 28, 129-41 (1980). 